THE KURUME MEDICAL JOURNAL

1975 Vol.22, No.1, P.17-22

\title{
SCANNING AND TRANSMISSION ELECTRON MICROSCOPIC OBSERVATIONS OF EPIPLEXUS CELLS (KOLMER CELLS) IN MONKEY BRAIN
}

\author{
TATSUO SHIMADA, KEN-DAN KŌ, \\ AND MASAHIRO MURAKAMI \\ Second Department of Anatomy, Kurume University School \\ of Medicine, Kurume, 830, Japan
}

(Received for publication January 4, 1975)

\begin{abstract}
A number of polymorphic cells can be observed with the scanning electron microscope on the ependymal surface of the choroid plexus in the monkey. These cells possess about 3-5 pseudopod-like processes, their end feet proceeding among the ependymal microvilli. It appears that these cells are exactly anchored to the choroidal epithelium in this manner. Further, for the purpose of a identification of these polymorphic cells, the same tissues are subsequently embedded in Epon, sectioned and re-examined under the light microscope and the transmission electron microscope. The ultrastructual observation reveals that the polymorphic cells possess numerous vacuoles, lysosomal dense bodies, and coated vesicles in the cytoplasm. It may be concluded that they correspond to "Kolmer cells" or "epiplexus cells" and hold a phagocytic nature.
\end{abstract}

The ependymal surface of the choroid plexus has been studied in many animals by means of scanning electron microscope (SEM). (Scoot, Paul and Dudley $1972^{10)}$, Clementi and Marini $1972^{5)}$, Weindl and Joynt $1972^{13)}$, Yamadori $1972^{14)}$, Scott, Van Dyke, Paul and Kozlowski $1974^{12)}$. However, the reports as to epiplexus cells (Kolmer cells) have only been demonstrated in rat (Hosoya and Fujita 1973) ${ }^{7}$ and in fetal rat (Chamberlain 1974) ${ }^{4}$. This paper describes ultrastructure of the epiplexus cells (Kolmer cells) in monkey by means of both scanning and transmission electron microscope.

\section{MATERIALS AND METHODS}

The experimental animals were adult male monkeys (Macaca fuscata) weighing $10-12 \mathrm{~kg}$. The animals were anesthetized with isozole and perfused via the $\mathrm{A}$. carotis communis with a mixture of $2 \%$ formaldehyde and $2.5 \%$ glutaraldehyde plus $0.025 \% \mathrm{CaCl}_{2}$ buffered with cacodylate $(\mathrm{pH} 7.4)$. The brain was excised as soon as possible and tissue blocks including the choroid plexus of both the lateral ventricle and the fourth ventricle were removed from the brain. After washing with saline solution throughout, they were immersed in the same fixative for 2 hours, then rinsed overnight in cold $0.1 \mathrm{M}$ cacodylate buffer, and postfixed in $2 \%$ osmium tetroxide. The fixed specimens were dehydelated in an ascending series of aceton and dried by Anderson's critical point drying method (1951) ${ }^{11}$. Following carbon and gold-palladium coating or gold 
spattering specimens were viewed through a field emission scanning electron microscope (HFS-2).

After observations were made in the SEM, the same specimens were placed into propylene oxide (or n-butyl glycidyl ether) for an hour, infiltrated with a mixture of propylene oxide (or nbuthyl glycidyl ether) and Epon 812 (1

:1) for three hours, and embedded in Epon 812. Ultrathin sections were made by a Sorvall MT-I microtome and the specimens double-stained with lead and uranyl acetate were examined with JEM -T7S electron microscope. Epon sections about 1-2 $\mu$ in thickness were also made and stained with buffered toluidine blue for light microscopy.

\section{OBSERVATIONS AND DISCUSSION}

In the scanning electron microscopic observation, the surface of the choroid plexus in monkey shows a complicatedly tortous appearance at low magnification (Fig. 1). The individual epithelial cells are somewhat convex and covered with closely arranged microvilli varying in profile from slender to polypoid one. Occationally a cluster of cilia can also be identified (Fig. 2).

Moreover, there are a number of polymorphic cells with elongated cytoplasmic processes on the surface of the choroid plexus in monkey (Figs. 1, 3 and 4). These cells conspicuously vary in shape, having generally flattened cell bodies. They possess pseudopod-like processes about 3-5 in number, from which numerous small processes emerge and extend among the ependymal microvilli. It appears that these cells are exactly anchored to the choroidal epithelium. On the basis of localization and appearance, the cells described may correspond to the epiplexus (Kolmer) cells which have been observed in a variety of vertebrate species by light and electron microscopy (Kolmer, 19218), AriënsKappers, 19532), Santoloza and Fchandia, 1968'), Carpenter, Mc Carthy and Borison, 1970) ${ }^{3)}$. Hosoya and Fujita (1973) ${ }^{7)}$ have found similar cells on the ependymal surface of the choroid plexus in rat brain under the SEM and posturated that they were scavengers belonging to the whole ventricular system. However, it is not always appropriate to assume the phogocytic nature of them only by scanning electron microscopy, because there were also found nerve cells on the ependymal cells in the brain ventricle (monkey: Coates $1973^{6}$ ), rabbit: Leonhardt und Lindemann 1973) ${ }^{9}$.

Accordingly, for the purpose of confirming the fine structure of these cells, the same tissues after observation by scanning electron microscopy, were embedded in Epon and re-examined by light and transmission electron microscopy. (Fig. 5) illustrates a light photograph of the choroid plexus of the monkey. Free cells are found to be closely juxtaposed to the free surface of the choroid epithelium. They have pseudopod-like processes, the nuclei usually being located eccentrically. The cytoplasm is faintly basophlic and contains a heterogenous population of vacuoles. At the ultrastructual level, the coating particles of gold or gold pailadium 250-500 $\AA$ thick layer are found on the surface of free cells as well as on microvilli and cilia of the choroidal epithelium. They have higher electron density. The free cells juxtaposed to the choroidal epithelium possess sparse mitochondria and the endoplasmic reticulum, free ribosomes, numerous membrane-limited vacuoles, and lysosomal dense bodies in the cytoplasm (Figs. 6 and 7). They have a structual characteristic suggestive of the so-called macrophage.

It may be assumed that they corres- 
pond to not nerve cells but to Kolmer cells or epiplexus cells with a phagocytic nature.

\section{REFERENCES}

1) Anderson, T.F.: Techniques for the preservation of three-dimensional structure in preparing specimens for the electron microscope. Trans. N. Y. Acad. Sci., 13, 130-134, 1951.

2 ) ARIËNS-Kappers, J.: Beitrag zur experimentellen Untersuchung von Funktion und Herkunft der Kolmerschen Zellen des Plexus chorioideus beim Axolotl und Meerschweinchen. Z. Anat. Entw. Gesch, 117, 1-19, 1953.

3 ) Garpenter, S. J., Mc Carthy, L. E. and BORISON, H. L. : Electron microscopic study on the epiplexus (Kolmer) cells of the cat choroid plexus. Z. Zellforsch., 110, 471-486, 1970.

4) Chamberlain, J. G.: Scanning electron microscopy of epiplexus cells (Macrophages) in the fetal rat brain (1). Amer. J. Anat., 139, 443-447, 1974.

5 ) Clementi,F. and Marini, D.: The surface fine structure of the walls of cerebral ventricles and of choroid plexus in cat. Z. Zellforsch., 123, 82-95, 1972.

6 ) Contes, P. W.: Supraependymal cells in recesses of the Monkey third ventricle. Amer. J. Anat., 136, 533-539, 1973.

7 ) Hosoy A, Y. and FujiTA, T. : Scanning electronmicroscope observation of intraventricular macrophages (Kolmer Cells) in the rat brain. Arch. Histol. Jap., 35, 133140, 1973.

8) Kolmer, W. : Über eine eigenartige Beziehung von Wanderzellen zu den Chorioidealplexus des Gehirns der Wirbeltiere.

Anat. Anz., 54, 15-19, 1921.

9) Leonhardt, H. und Lindemann, B.: Über ein supraependymales Nervenzell-, Axonund Gliazellsystem. Z. Zellforsch., 139, 285-302, 1973.

10) Santolaya, R.C. and Echaudia, E. L.R. : The surface of the choroid plexus cell under nomal and experimental conditions. Z. Zellforsch., 92, 43-51, 1968.

11) Scott,D.E., Paull, W.K. and Dudley,G.
K. : A comparative scanning electron microscopic analysis of the human cerebral ventricular system. I. The third ventricle. Z. Zellforsch., 132, 203-215, 1972.

12) Scott, D.E., Van Dyke, D. H., Paull, W. K. and Kozlowski, G. P. : Ultrastructural analysis of the human cerebral ventricular system. III. The choroid plexus. Cell Tiss. Res., 150, 389-397, 1974.

13) Weinde, A. and Joynt, R.J.: Ultrastructure of the ventricular walls. Arch. Neurol, 26, 420-427, 1972.

14) Yamadori, T. : A scanning electron microscopic observation of the choroid plexus in rats. Arch. Histol. Jap., 35, 89-97, 1972.

\section{EXPLANATION OF FIGURES}

Fig. 1. Scanning electron micrograph of the choroid plexus in the lateral ventricle of the monkey. At low magnification the choroid plexus shows complicatedly convoluted contours. On the ependymal surface of the choroid plexus, a number of free cells (arrows) are observable. $\times 150$

Fig. 2. The surface of the epithelial cells of the choroid plexus is covered with numerous microvilli and cilia. $\times 30.000$

Fig. 3. A part of the choroid plexus in the lateral ventricle. A polymorphic, free cell with pseudopod-like processes is closely juxtaposed to the ependymal surface. EC: epithelial cells. FC: free cell. $\times .4 .000$

Fig. 4. Higher magnification of Fig. 2. A part of the pseudopod-like processes of polymorphic cell. Note the end-feet proceeding among the ependymal microvilli. $\times 9.000$

Fig. 5. Light micrograph of Epon-embedded tissues after observation by the SEM. Arrows indicate the so-called epiplexus cells situated along the surface of the choroidal villi. $\mathrm{CE}$ : choroidal epithelium.

Fig. 6. Transmission electron micrograph of an epiplexus cell after observation by the SEM. A particulate gold coating (250-500 $\AA$ in thickness) is found (arrow). The epiplexus cell contains numerous vacuoles and lysosomal dense bodies. $\times 10.000$

Fig. 7. A part of the epiplexus cell with lysosomal dense bodies. $\times 32.000$ 

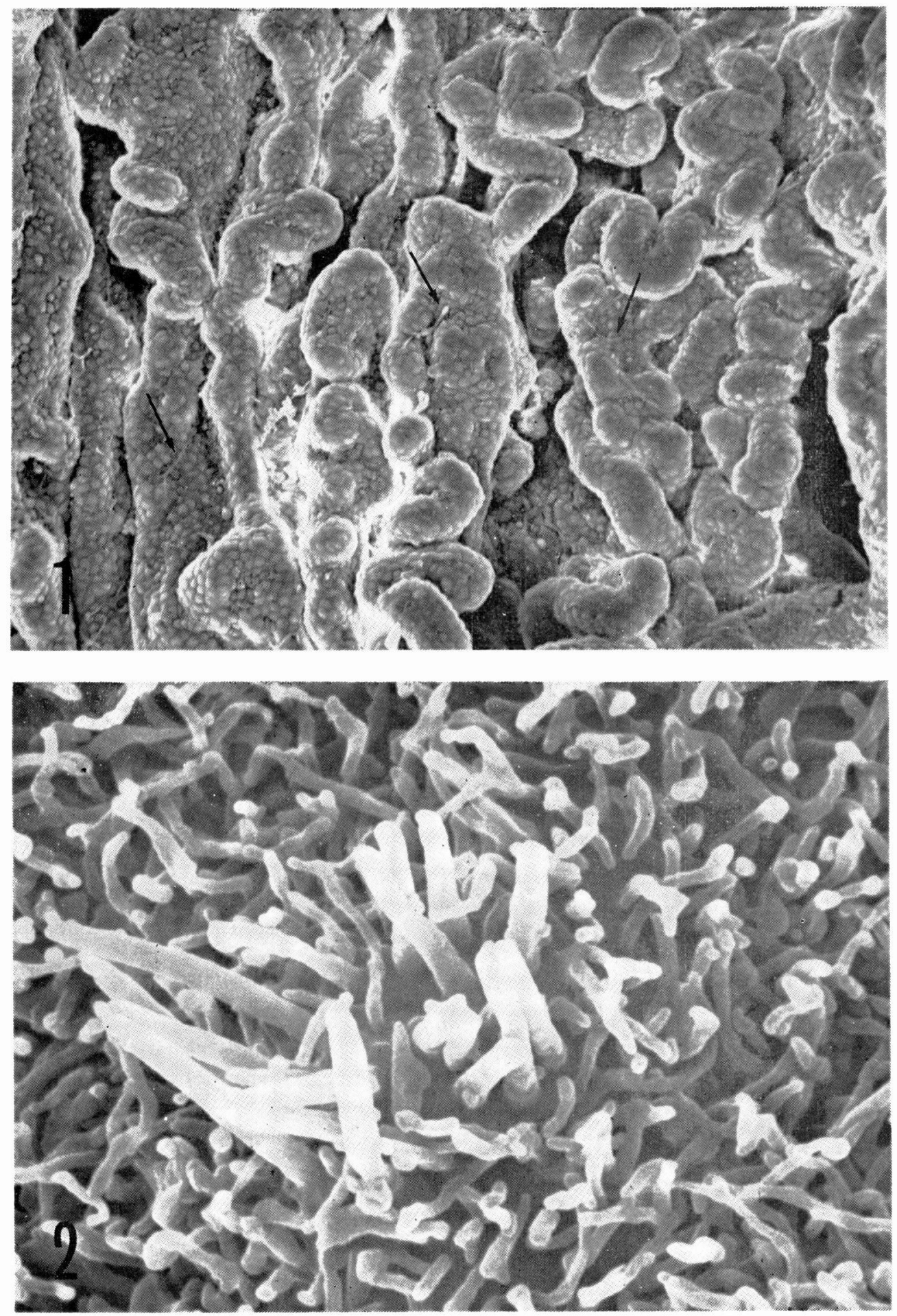

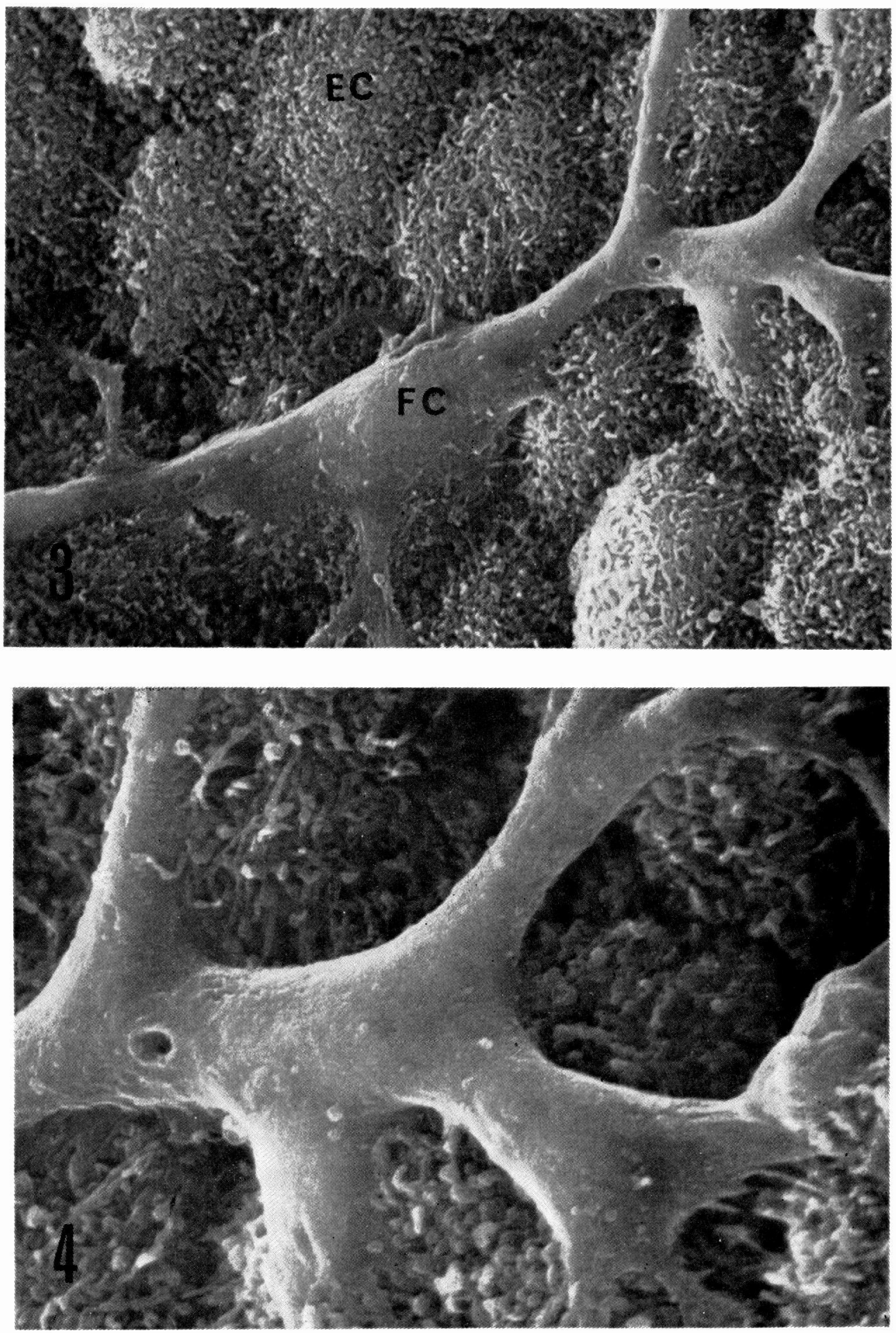

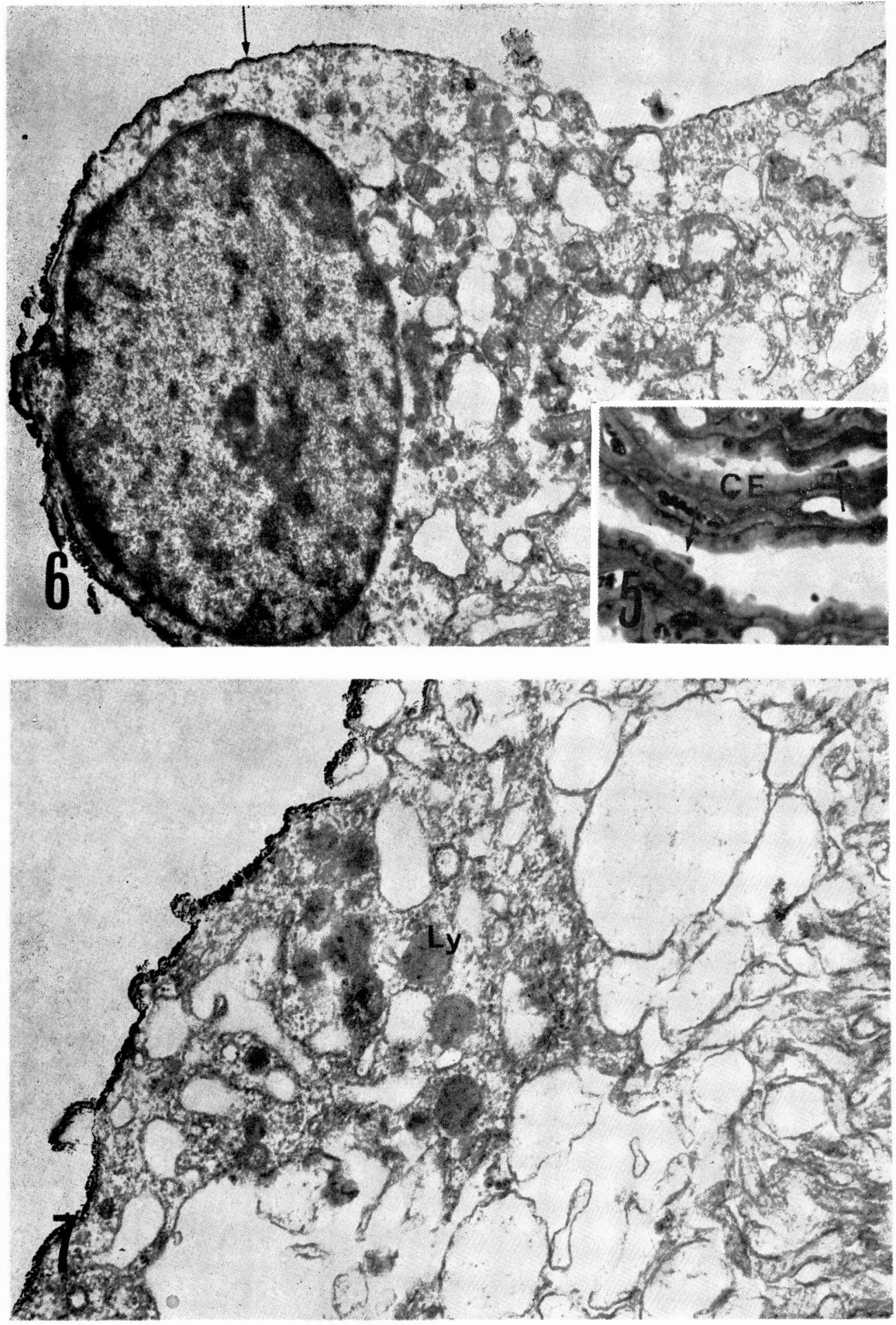